\title{
Identification of Mulberry Dwarf Phytoplasmas in the Genital Organs and Eggs of Leafhopper Hishimonoides sellatiformis
}

\author{
H. Kawakita, T. Saiki, W. Wei, W. Mitsuhashi, K. Watanabe, and M. Sato
}

National Institute of Sericultural and Entomological Science, Tsukuba, Ibaraki 305-8634, Japan.

Accepted for publication 8 May 2000.

\section{ABSTRACT}

Kawakita, H., Saiki, T., Wei, W., Mitsuhashi, W., Watanabe, K., and Sato, M. 2000. Identification of mulberry dwarf phytoplasmas in the genital organs and eggs of leafhopper Hishimonoides sellatiformis. Phytopathology 90:909-914.

The presence of mulberry dwarf (MD) phytoplasmas in organs of the inoculative vector insects Hishimonoides sellatiformis and Hishimonus sellatus was determined by means of electron microscopy (EM) and polymerase chain reaction (PCR) assays. Many MD phytoplasmas were detected in genital organs as well as in the intestines, salivary glands, brains, fat bodies, and thoracic ganglia of Hishimonoides sellatiformis, but only in the intestine and salivary glands of Hishimonus sellatus. Many phytoplasmas with characteristic morphology were observed via EM in ovaries, seminal receptacles, and testes, and they were further identified by PCR assays with group I-specific primers. In addition, the organisms were detected by direct or nested PCR assays in eggs (head pigmentation stage of embryos) laid on mulberry shoots by inoculative leafhoppers and in the newly hatched nymphs from these eggs. These findings indicate that transovarial transmission of MD phytoplasmas occurs in Hishimonoides sellatiformis.
The life cycle of phytoplasmas (plant-pathogenic mollicutes) in insect vectors has been considered as follows: phytoplasmas residing in phloem sieve tubes are ingested by an insect; they multiply first in its intestinal cells and pass into its hemolymph; and they infect various internal organs, such as salivary glands, thoracic ganglia, and fat bodies. Most types of phytoplasmas were not believed to infect genital organs; therefore, phytoplasmas have not been believed to transmit vertically to the next generation of the vector insect. Aster yellows (AY) phytoplasmas have been reported to irregularly infect the ovaries but not the testes of Macrosteles fascifrons; a report supported by transmission experiments using the extracts of organs (18). In recent years, Alma et al. (1), using a nested polymerase chain reaction (PCR) assay, detected AY phytoplasmas in eggs and newly hatched nymphs of Scaphoideus titanus reared on healthy plants, suggesting the transovarial transmission of AY phytoplasmas in insect vectors. They did not try, however, to observe AY phytoplasmas in the genital organs of the leafhopper by electron microscopy (EM), which would have constituted important direct evidence of transovarial transmission.

Several classification systems of phytoplasmas have been proposed either directly based on sequence analysis or indirectly based on restriction fragment length polymorphism (RFLP) analysis of PCR-amplified 16S rDNA $(6,10,11,17)$. Approximately 14 groups of phytoplasmas were proposed $(3,6)$. Mulberry dwarf (MD) phytoplasma belongs to the phytoplasma taxonomic group I (16SrI-B; AY group), with AY Paulownia witches' broom and onion yellows (OY) phytoplasmas $(6,11)$.

MD phytoplasmas are transmitted by two species of leafhoppers, Hishimonus sellatus and Hishimonoides sellatiformis, in mulberry fields. The phytoplasmas are more efficiently transmitted by the latter than by the former (4), suggesting that MD phytoplasmas may have the ability to grow in several organs of Hishimonoides sellatiformis. Generally, phytoplasmas are easily detectable by EM in the intestines, hemolymph, and salivary

Corresponding author: M. Sato; E-mail address: satomamo@nises.affrc.go.jp

Publication no. P-2000-0623-01R

(C) 2000 The American Phytopathological Society glands of most insect vectors but are not always detectable in organs, such as Malpighian tubules, fat bodies, mycetomes, thoracic ganglia, and brains. For instance, Western X (WX) disease and flavescence dorée (FD) phytoplasmas were observed in the brain, fat bodies, and mycetomes of Colladonus montanus (12) and Euscelidius variegatus (8), whereas AY phytoplasmas were not found in these organs of $M$. fascifrons (18).

In the present study, we compared the distributions of MD phytoplasmas in the organs of two insect vectors, Hishimonoides sellatiformis and Hishimonus sellatus. MD phytoplasmas were observed by EM in the genital organs of Hishimonoides sellatiformis, but not in the same organs of Hishimonus sellatus. With a PCR assay, we looked for MD phytoplasmas in eggs laid on mulberry shoots and in nymphs newly hatched from these eggs. Our results are consistent with the interpretation that transovarial transmission occurs in Hishimonoides sellatiformis.

\section{MATERIALS AND METHODS}

Insects. Inoculative Hishimonoides sellatiformis (Hishimonmodoki in Japanese) and rhombic-marked Hishimonus sellatus leafhoppers (Hishimon-yokobai in Japanese) were collected more than 30 days after feeding on MD-diseased mulberry trees. Each insect's organs, including intestines, salivary glands, Malpighian tubules, fat bodies, mycetomes, thoracic ganglia, brains, and genitals were carefully collected from their bodies and washed several times in saline solution. Yellow fat bodies, which adhere to the tips of genital organs (ovaries, seminal receptacles, and testes; Fig. 1E and 1F), were completely excised. Each organ was used for EM observation and PCR assays to detect MD phytoplasmas.

Eggs laid by inoculative Hishimonoides sellatiformis on mulberry shoots and nymphs (first instar) hatched from these eggs were used for EM and PCR assay. The sampled eggs were in the head pigmentation stage just before hatching. Each PCR sample contained five eggs. Newly hatched nymphs were collected several days after hatching.

EM. Samples were prefixed in $2.5 \%$ glutaraldehyde $(0.1 \mathrm{M}$ phosphate buffer, $\mathrm{pH} 7.3$ ) for $2 \mathrm{~h}$ at $4^{\circ} \mathrm{C}$, postfixed in $1 \%$ osmic acid for $1.5 \mathrm{~h}$ at $4^{\circ} \mathrm{C}$, dehydrated with an ethanol series, and em- 
TABLE 1. Detection of mulberry dwarf (MD) phytoplasmas in organs of inoculative leafhoppers Hishimonus sellatus and Hishimonoides sellatiformis by electron microscopy $(\mathrm{EM})^{\mathrm{z}}$

\begin{tabular}{lcc}
\hline Organ & Hishimonus sellatus & Hishimonoides sellatiformis \\
\hline Salivary glands & $5 / 5$ & $5 / 5$ \\
Brain & $0 / 5$ & $2 / 5$ \\
Thoracic ganglions & $0 / 5$ & $2 / 5$ \\
Intestines & $3 / 5$ & $5 / 5$ \\
Fat bodies & $0 / 5$ & $3 / 5$ \\
Malpighian tubules & $0 / 5$ & $0 / 5$ \\
Mycetomes & $0 / 5$ & $0 / 5$ \\
\hline
\end{tabular}

${ }^{\mathrm{z}}$ Five organs collected from five inoculative leafhoppers 40 days after beginning of acquisition were used for EM observation. All tested leafhoppers were infected with MD phytoplasmas as confirmed by the presence of the organisms in their salivary glands $(5 / 5=5$ positive samples of 5 tested samples). Other organs of the same leafhopper were examined by EM. bedded in Epon 812 resin. Ultrathin sections were made with an ultramicrotome (LKB 4800, LKB Products, Bromma, Sweden) and subjected to electron microscopy (JEM 1010, JEOL, Tokyo) after staining with uranyl acetate and lead citrate.

Template DNA preparation. Template DNA from insect organs was prepared according to the cetyltrimethylammoniumbromide (CTAB) method $(10,16)$. Briefly, samples from organs, eggs, and newly hatched nymphs were ground in an Eppendorf tube $(1.5 \mathrm{ml})$ or a mortar with $400 \mu \mathrm{l}$ of extraction buffer $(100 \mathrm{mM}$ Tris, 1.4 $\mathrm{M} \mathrm{NaCl}, 1 \%$ polyvinylpyrrolidone [PVP], 2\% CTAB, $20 \mathrm{mM}$ EDTA, $\mathrm{pH}$ 8.0) by a homogenizer or a pestle, respectively, incubated at $65^{\circ} \mathrm{C}$ for $30 \mathrm{~min}$, and centrifuged $(1,200 \times g$ for $5 \mathrm{~min})$. An equal volume of chloroform-isoamyl alcohol (24:1) was added to the supernatant, and the mixture was centrifuged again. A 0.7 volume of isopropyl alcohol was added to the supernatant and was incubated at $-20^{\circ} \mathrm{C}$ overnight. The pellet obtained after centrifugation was dissolved in $50 \mu \mathrm{l}$ of distilled water, and the resultant solution was used as a template DNA for direct PCR amplification.
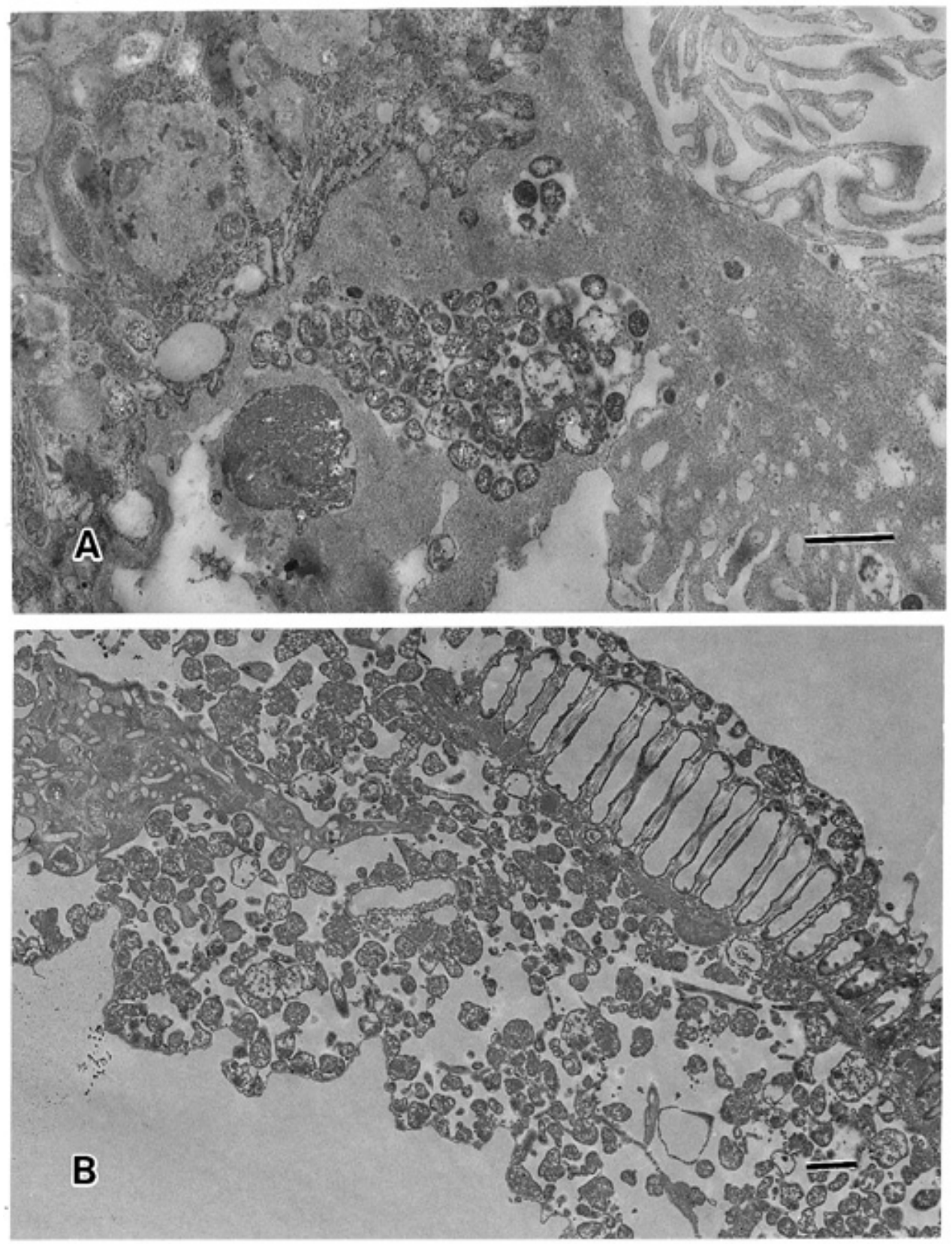

(Continued on next page)

Fig. 1. A to D, Transmission electron and $\mathbf{E}$ and $\mathbf{F}$, light micrographs of genital organs and sperm cells of Hishimonoides sellatiformis. Mulberry dwarf phytoplasmas can be seen in $\mathbf{A}$, ovaries, $\mathbf{B}$, testes, and $\mathbf{C}$, seminal receptacles, but not $\mathbf{D}$, sperm cells (cross- or vertical sections). $\mathbf{E}$ and $\mathbf{F}$, Ovaries and testes at $15 \times$ magnification. $\mathbf{E}$, The arrow indicates a seminal receptacle. A to $\mathbf{D}$, Scale bars represent $1 \mu \mathrm{m}$. E and F, Scale bars represent $50 \mu \mathrm{m}$. 
PCR analyses. A sample of $2.5 \mu \mathrm{l}$ of template DNA solution, prepared as described in the preceding section, was used in a PCR reaction mixture $(50 \mu \mathrm{l})$. Direct PCR amplification was performed according to Lee et al. (5,7). For nested PCR assays, direct PCR products diluted at 1:50 in distilled water were used as template DNAs. The universal primer set (R16F1/R0) and phytoplasma group I-specific primer set (R16(I)F1/R1) were used for direct and nested PCRs, respectively $(5,7)$. The PCR products were analyzed by electrophoresis through $1 \%$ agarose gel and stained with ethidium bromide. The size of the PCR products were estimated by standard markers, $\lambda$ phage DNA digested with HindIII and EcoRI (Toyobo, Tokyo).

PCR products were digested with restriction enzyme MseI (New England Biolabs, Beverly, MA), AluI, HpaII, or HhaI (Toyobo), and the products were separated by electrophoresis with

Fig. 1. (continued from preceding page)
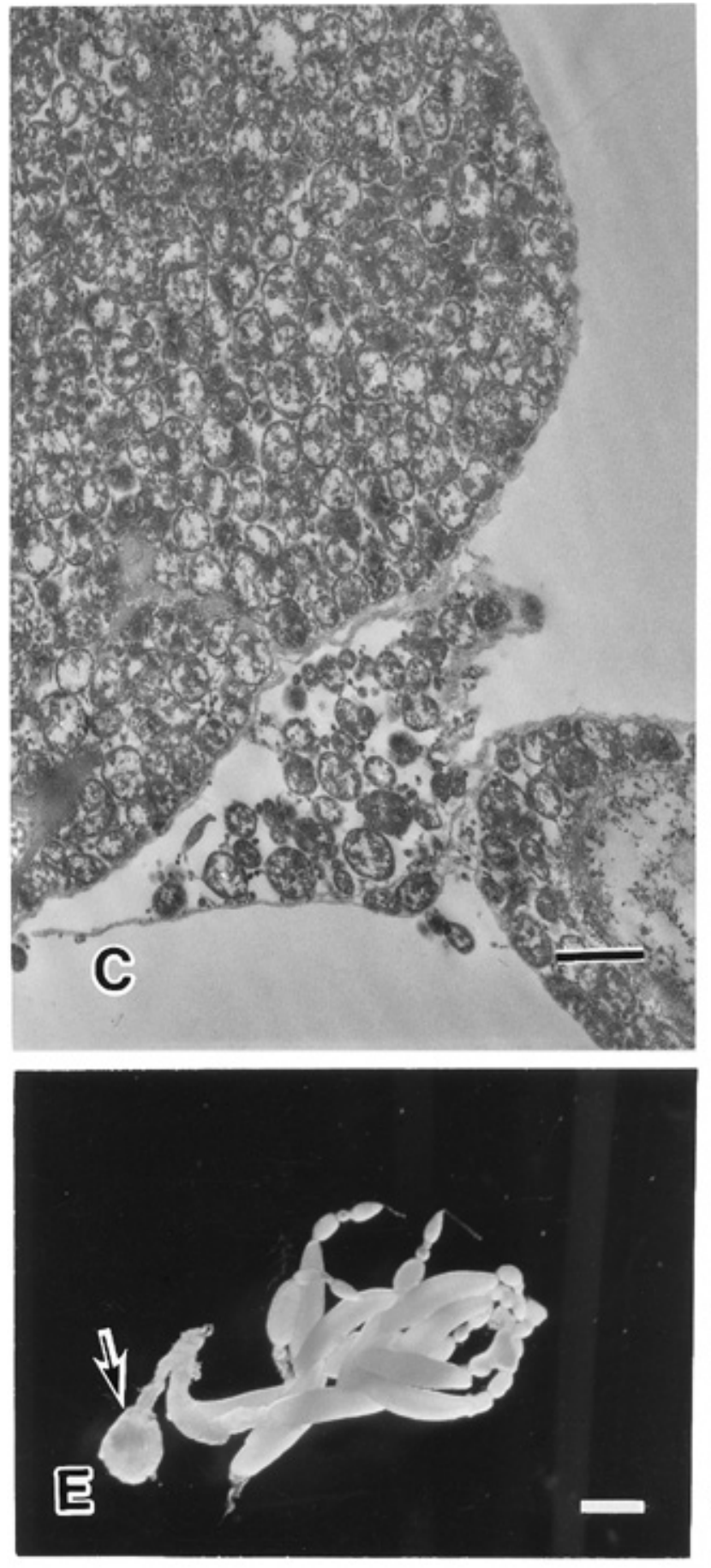

3\% NuSieve GTG agarose gel (FMC Bioproducts, Rockland, $\mathrm{MD})$. The molecular weights of the restriction fragments were estimated with standard markers, $\phi X 174$ DNA digested with HintI (Nippon Gene, Tokyo).

\section{RESULTS}

Detection of phytoplasmas in various organs. Five inoculative leafhoppers of each species of Hishimonus sellatus and Hishimonoides sellatiformis, of which salivary glands were confirmed by EM to be inoculated, were used 40 days after feeding. As shown in Table 1, MD phytoplasmas were detected only in the salivary glands (anterior and posterior lobes) and intestines (epithelial cells of midguts) of Hishimonus sellatus. In contrast, MD phytoplasmas were detected in the brain, fat bodies, thoracic ganglia,
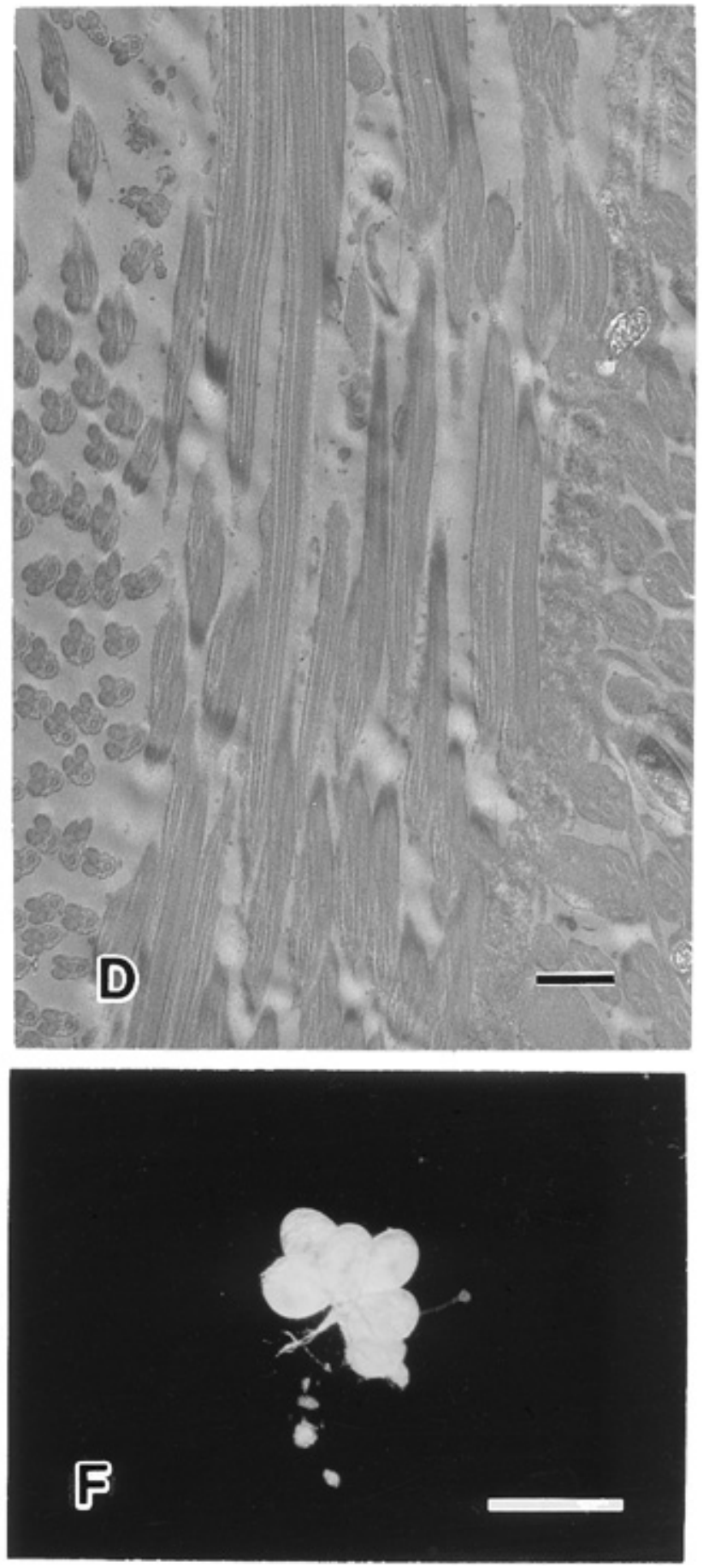
salivary glands (anterior and posterior lobes), and intestines (midguts) of Hishimonoides sellatiformis. Phytoplasmas were not seen in the Malpighian tubules or mycetomes of either leafhopper species. Phytoplasmas in each organ were identified as AY group phytoplasmas by direct PCR and nested PCR, in which groupspecific primers were used (data not shown).

Detection of phytoplasmas in genital organs. Four or five genital organs, including the ovaries, seminal receptacles, and testes from five inoculative Hishimonoides sellatiformis (Fig. 1E and $1 F$ ), were used for EM observation and PCR assay. MD phytoplasmas were observed in all of these genital organs by EM, as shown in Figure 1A (ovaries), 1B (testes), and 1C (seminal receptacles). MD phytoplasmas in these genital organs were almost the same as those in salivary glands in their morphology. Lacking a cell wall, they are bound by a plasma membrane, are polymorphic within a diameter of 0.1 to $0.6 \mu \mathrm{m}$ (average $0.3 \mu \mathrm{m}$ ), and contain typical prokaryotic ribosomes. Thus, they have the characteristic morphology of phytoplasmas. Direct and nested PCR analyses also revealed that MD phytoplasmas were present in

TABLE 2. Detection of mulberry dwarf phytoplasmas in the genital organs and eggs of inoculative adult leafhoppers (Hishimonoides sellatiformis) by direct polymerase chain reaction (PCR) and nested PCR

\begin{tabular}{lcc}
\hline Organ and eggs & Direct PCR & Nested PCR \\
\hline Group a & & \\
Ovaries (4) & + & + \\
Testes (6) & + & + \\
Group b & + & + \\
Ovaries-1 (3) & - & + \\
Ovaries-2 (2) & $(+)$ & + \\
Seminal receptacles (5) & - & + \\
Testes (3) & - & + \\
Egg samples & - & - \\
A (5) & - & + \\
B (5) & - & + \\
C (5) & - & \\
D (5) & &
\end{tabular}

y Group a samples were collected on 24 August 1998 from leafhoppers reared on diseased plants for 52 days. Group b samples were collected on 25 November 1998 from leafhoppers reared on diseased plants for 50 days. Numbers in parentheses show the numbers of organs included in one sample used for PCR. Ovaries-1 and -2 are mature and immature ovaries, respectively. Egg samples A and B represent head pigmentation stage (growth stage of embryo), and C and D represent eggs that failed to hatch following development to the head pigmentation stage due to phytoplasma infection or other reasons.

${ }^{\mathrm{z}}(+)$ indicates a weak PCR signal; + indicates a strong signal; - indicates no signal.

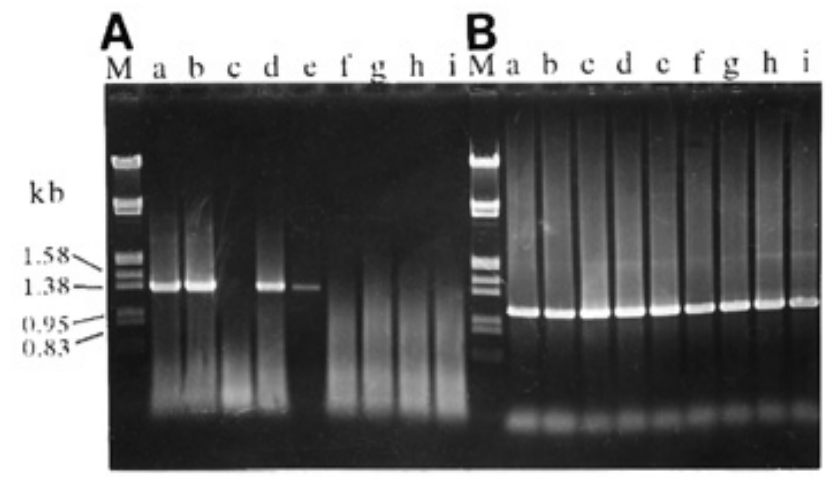

Fig. 2. A, Direct polymerase chain reaction (PCR), and B, nested PCR using DNA templates extracted from the genital organs and eggs of inoculative Hishimonoides sellatiformis. Lanes $\mathrm{M}=$ marker 2 ( $\lambda$ DNA digested with HindIII and EcoRI); a-c = ovaries; $\mathrm{d}=$ testes; $\mathrm{e}=$ seminal receptacles; $\mathrm{f}-\mathrm{g}=$ eggs $($ head pigmentation stage); h-I = eggs (nonhatching eggs over head pigmentation stage). Ovaries (a) and testes (b) were prepared from group a (Table 2), and ovaries (b and c) were prepared from group b. All egg samples are described in Table 2. these organs, although in some cases phytoplasmas were detected only through nested PCR. (Table 2, Fig. 2).

Detection of phytoplasmas in eggs and newly hatched nymphs. Direct PCR amplification with universal primer pairs R16F1/R0 did not produce detectable products for eggs. By subsequent nested PCR, however, MD phytoplasmas were detected in three of four samples (each sample contained five eggs) (Table 2, Fig. 2). By direct PCR, MD phytoplasmas were detected in two of four samples (each sample contained five to seven nymphs) of newly hatched nymphs from eggs laid on shoots; all four samples were positive based on further nested PCR. In contrast, no PCR product was detected in any sample of nymphs hatched from eggs laid on healthy shoots of three samples (each sample contained seven nymphs).

Molecular analyses of amplified DNAs. To confirm that the DNA fragments amplified by PCR had originated from 16S rRNA genes of MD phytoplasma, PCR products were analyzed by restriction enzyme digestion. The 1.1-kb DNA amplified by the nested primer pairs was digested with $M s e I$, and the resultant pattern clearly showed typical RFLPs $(6,7)$ with phytoplasmas belonging to group I (Fig. 3). Similarly, AluI, HpaII, and HhaI digestion patterns also showed the same patterns as group I (data not shown).

\section{DISCUSSION}

Two species of leafhoppers, Hishimonus sellatus and Hishimonoides sellatiformis, are vectors of MD phytoplasmas. In the present study, we demonstrated that MD phytoplasmas infect a greater number of organs in Hishimonoides sellatiformis than in Hishimonus sellatus (Table 1). Furthermore, EM and PCR assays detected MD phytoplasmas in the ovaries and seminal receptacles of female adults and testes of male adults of Hishimonoides sellatiformis. These organ specimens were prepared very carefully. Fat bodies attached to these organs were completely removed to maintain the purity of the specimens. In addition, specimens for EM observation were identified by the characteristic structure of each organ, as shown in Figure 1. To our knowledge, this is the first report of EM observation of phytoplasmas in the genital or-

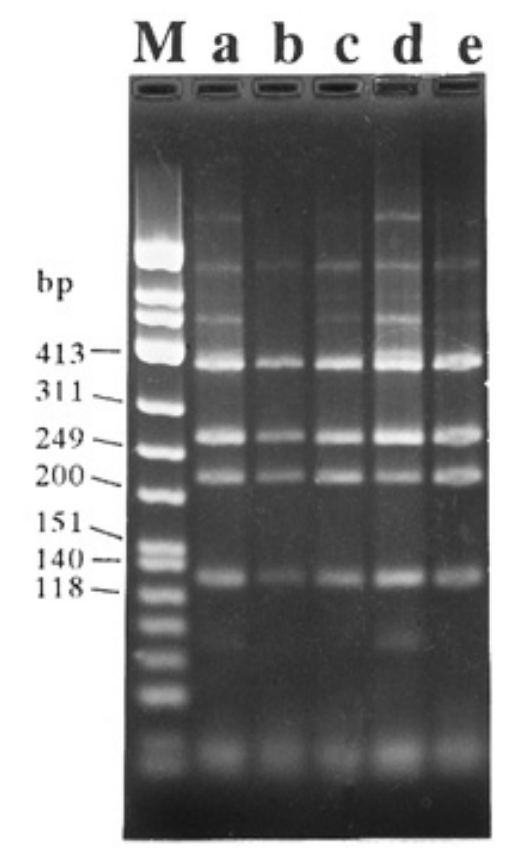

Fig. 3. MseI-digestion pattern of $16 \mathrm{~S}$ rDNA amplified by nested polymerase chain reaction by DNA templates extracted from genital organs and eggs of inoculative Hishimonoides sellatiformis. Lanes $M=$ marker $9(\phi X 174$ DNA digested with HintI ); $\mathrm{a}=$ ovaries; $\mathrm{b}=$ testes; $\mathrm{c}=$ seminal receptacles; $\mathrm{d}=$ eggs (head pigmentation stage); and e = eggs (nonhatching eggs beyond head pigmentation stage). 
gans of insect vectors. Sinha and Chiykowski (18) indicated the presence of AY phytoplasmas in ovaries but not in testes based on the bioassay method of injecting extracts into healthy leafhoppers. However, the EM observation of AY phytoplasmas in ovaries was not performed in that study (18). WX and FD phytoplasmas were detected by EM in various organs, including brain, fat bodies, and mycetome but not in the ovaries and testes of Colladonus montanus and Euscelidius variegatus $(8,12)$.

Several types of prokaryotic symbionts have been reported to be present in genital organs of insects including leafhoppers. We also observed rod-shaped bacteria $(1 \times 0.3 \mu \mathrm{m})$, which are easily distinguished from phytoplasmas, in genital organs of Hishimonoides sellatiformis (H. Kawakita, T. Saiki, W. Wei, W. Mitsuhashi, K. Watanabe, and M. Sato, unpublished data). The colonizing site in the genital organs of these microorganisms was very different from that of MD phytoplasmas. Other types of symbionts were not detected in this leafhopper.

The presence of MD phytoplasmas in genital organs may affect the reproductive ability of Hishimonoides sellatiformis. We observed many unhatched eggs laid by inoculative leafhoppers. In addition, we detected MD phytoplasmas in unhatched eggs kept for more than 10 days beyond the head pigmentation stage (Table 2). These findings suggest that ovaries infected with phytoplasmas may have impaired function compared with "healthy" ovaries. On the other hand, Wolbachia is a common and widespread genus of bacteria found in the genital organs of invertebrates, primarily insects. This organism is known to manipulate or inhibit the reproduction of its host by mechanisms, including induction of reproductive incompatibility, parthenogenesis (female production from unfertilized eggs), and feminization of genetic males (15). It has not yet been confirmed whether phytoplasmas can affect the reproduction of the host insect. This possibility has not been completely eliminated, because our study showed that phytoplasmas can survive in genital organs.

Many MD phytoplasmas were also detected in the seminal receptacles of female adults and in the testes of male adults, suggesting that MD phytoplasmas might be transferred into female adults from infected male adults through copulation. Some phytoplasmas have been reported to be transmitted transovarially in their insect vectors. Posnette and Ellenberger (14) suggested that clover phyllody phytoplasma may be transmitted to the next generation, because Euscelis incisus (Kirschbaum) nymphs developing from eggs laid on wheat plants by infected females were able to infect healthy clover plants. Wheat plants however, were susceptible to this phytoplasma (2); therefore, this study should be reconfirmed in additional plants. Recently, Alma et al. (1) used nested PCR assay to detect AY phytoplasmas in eggs and newly hatched nymphs of Scaphoideus titanus. They detected AY phytoplasmas in 5 egg batches of 10, and in 6 batches of reared nymphs of 7 through nested PCR assays with R16(1)F1/R1, although they could not detect AY phytoplasmas by direct PCR amplification with universal primer pairs R16F1/R0 or R16F2/R2. This strongly suggests that AY phytoplasmas in vector insects can be transmitted transovarially.

We obtained similar results, indicating the possibility of transovarial transmission of MD phytoplasmas in the vector Hishimonoides sellatiformis. We frequently detected MD phytoplasmas in ovaries and seminal receptacles by EM and PCR. In addition, the organisms were detected in eggs laid by inoculative Hishimonoides sellatiformis on mulberry shoots. We detected MD phytoplasmas in three egg samples of four by further nested PCR assays with R16(1)F1/R1 following direct PCR with R16F1/R0, suggesting a low population of the organisms in eggs (or template DNAs). We could not show the presence of MD phytoplasmas in eggs by means of EM, because the hard egg shells make preparation of ultrathin sections very difficult. In addition, using direct PCR and nested PCR, we detected MD phytoplasmas in each of four batches of newly hatched nymphs (first instar) taken from diseased mulberry trees, while no phytoplasmas were detected in any of three newly hatched nymph batches taken from healthy plants. Our data for newly hatched nymphs also may support the assumption that MD phytoplasmas can be transmitted vertically. However, newly hatched nymphs, which were used in our PCR analyses, may feed on diseased mulberry trees phloem sap after hatching, although for a short time. Because nested PCR is a very sensitive detection method, MD phytoplasmas acquired after hatching should be detectable by nested PCR. Regardless of the method, it is very difficult to separate hatched nymphs completely from MD phytoplasma-infected shoots prior to ingesting. Nevertheless, based on our results, we propose that MD phytoplasmas are transmitted at least at a low frequency to the next generation of Hishimonoides sellatiformis. After we establish an effective procedure for collecting newly hatched nymphs prior to their feeding on phloem sap containing MD phytoplasmas, we will investigate how frequently vertical transfer of MD phytoplasmas in Hishimonoides sellatiformis occurs.

Interestingly, both AY and MD phytoplasmas are transferred transovarially in their insect vectors and belong to group I. Recently, Neimark and Kirkpatrik (13) isolated full lengths of phytoplasma chromosomes and estimated their genome sizes (640 to $1,185 \mathrm{~kb}$ ). More recently, Marcone et al. (9) estimated full-length chromosomes of 71 strains of phytoplasmas belonging to 12 major phylogenic groups, including several AY subgroups, by pulsedfield gels. Considerable variation in genome size, from 660 to $1,130 \mathrm{~kb}$, was observed among the AY group (group I). The variation in genome sizes in the AY group of phytoplasmas indicates that different amounts of genomic material have been lost in their evolution. These findings suggest that AY group phytoplasmas vary in their phenotypes, including survival in genital organs and successive transovarial transmission of phytoplasmas in leafhoppers. We speculate that only a few strains of phytoplasmas (with specified genomic materials) have become transovarially transmissible and probably only in limited species of leafhoppers, such as those with a mature host-parasite relationship.

\section{LITERATURE CITED}

1. Alma, A., Bosco, D., Danielli, A., Bertaccini, A., Vibio, M., and Arzone, A. 1997. Identification of phytoplasmas in eggs, nymphs, and adults of Scaphoideus titanus Ball reared on healthy plants. Insect Mol. Biol. 6:115-121.

2. Chiykowski, L. N. 1967. Some host plants of a Canadian isolate of the clover phylody virus. Can. J. Plant Sci. 47:141-148.

3. International Committee on Systematic Bacteriology: Subcommittee on the Taxonomy of Mollicutes. 1997. Minutes of the interim meetings. Int. J. Syst. Bacteriol. 47:911-914.

4. Ishizima, T. 1971. Transmission of the possible pathogen of mulberry dwarf disease by a new leafhopper vector, Hishimonoides sellatiformis Ishihara. J. Seric. Sci. Jpn. 40:136-140.

5. Lee, I. M., Bertaccini, A., Vibio, M., and Gundersen, D. E. 1995. Detection of multiple phytoplasmas in perennial fruit trees with decline symptoms in Italy. Phytopathology 85:728-735.

6. Lee, I. M., Gundersen-Rindal, D. E., Davis, R. E., and Bartoszyk, I. M. 1998. Revised classification scheme of phytoplasmas based on RFLP analysis of $16 \mathrm{~S}$ rRNA and ribosomal protein gene sequences. Int. J. Syst. Bacteriol. 48:1153-1169.

7. Lee, I. M., Hammond, R. W., Davis, R. E., and Gundersen, D. E. 1993. Universal amplification and analysis of pathogen 16S rRNA for classification and identification of mycoplasmalike organisms. Phytopathology. 83:834-842.

8. Lefol, C., Lherminier, J., Boudon-Padieu, E., Larrue, J., Louis, C., and Caudwell, A. 1994. Propagation of flavescence dorée MLO in the leafhopper Euscelidius variengatus. J. Invertebr. Pathol. 63:285-293.

9. Marcone, C., Neimark, H., Ragozzino, A., Lauer, U., and Seemüller, E. 1999. Chromosome sizes of phytoplasmas composing major phylogenetic groups and subgroups. Phytopathology 89:805-810.

10. Namba, S., Kato, S., Iwanami, S., Oyaizu, H., Shiozawa, H., and Tsuchizaki, T. 1993. Detection and differentiation of plant-pathogenic mycoplasmalike organisms using polymerase chain reaction. Phytopathology 83:786-791.

11. Namba, S., Oyaizu, H., Kato, S., Iwanami, S., and Tsuchizaki, T. 1993. 
Phylogenetic diversity of phytopathogenic mycoplasmalike organisms. Int. J. Syst. Bacteriol. 43:461-467.

12. Nasu, S., Jensen, D. D., and Richardson, J. 1970. Electron microscopy of mycoplasmalike bodies associated with insect and plant hosts of peach Western X-disease. Virology 41:583-595.

13. Neimark, H., and Kirkpatrick, B. C. 1993. Isolation and characterization of full-length chromosomes from nonculturable plant-pathogenic mycoplasma-like organisms. Mol. Microbiol. 7:21-28.

14. Posnette, A. F., and Ellenberger, C. E. 1963. Further studies of green petal and other leafhopper-transmitted viruses infecting strawberry and clover. Ann. Appl. Biol. 51:69-83.
15. Rousset, F., Bouchon, D., Pintureau, B., Juchault, J., and Solignac, M. 1992. Wolbachia endosymbionts responsible for various alterations of sexuality in arthropods. Proc. R. Soc. Lond. Ser. B Biol. Sci. 250:91-98.

16. Sato, M., Mitsuhashi, W., Watanabe, K., and Kawakita, H. 1996. PCR detection of mulberry dwarf disease-phytoplasmas in mulberry tissues, phloem sap collected by laser stylectomy and insect vector Hishimonus sellatus. J. Seric. Sci. Jpn. 65:352-358.

17. Seemüller, E., Marcone, C., Lauer, U., Ragozzino, A., and Göschl, M. 1998. Current status of molecular classification of the phytoplasmas. J. Plant Pathol. 80:3-26.

18. Sinha, R. C., and Chiykowski, L. N. 1967. Initial and subsequent sites of aster yellows virus infection in a leafhopper vector. Virology 33:702-708. 